\title{
STATISTIEK EN INFERENSIE*
}

\section{Inleidend:}

Een van die mees vooraanstaande wiskundiges wat hierdie eeu geleef het, Von Neumann,' het een keer 'n voordrag met die volgende opmerking ingelei:

"A discussion of the nature of intellectual work is a difficult task in any field, even in fields which are not so far removed from the central area of our common human intellectual effort as mathematics still is. A discussion of the nature of intellectual effort is difficult per se - at any rate, more difficult than the mere exercise of that particular effort. It is harder to understand the mechanism of an airplane, and the theories of the forces which lift and which propel it, than merely to ride in it, to be elevated and transported by it or even to steer it. It is exceptional that one should be able to acquire the understanding of a process without having previously acquired a deep familiarity with running it, with using it, before one has assimilated it in an instinctive and empirical way.

Thus any discussion of the nature of intellectual effort in any field is difficult, unless it presupposes an easy, routine familiarity with that field. In mathematics this limitation becomes very severe if the discussion is to be kept on a nonmathematical plane. The discussion will then necessarily show some very bad features; points which are made can never be properly documented; and a certain over-all superficiality of the discussion becomes unavoidable."

Vervang ons hier „Wiskunde" deur ,Statistiek", wat in sy wese eintlik ook maar net 'n tak van Wiskunde is, dan is hierdie opmerking ook van toepassing op wat ek gaan sê. Ek is dus terdeë bewus van die moeilikhede wat hieruit ontstaan en van die tekortkominge in my voordrag waartoe dit aanleiding gee; nogtans vind ek dit 'n aangename taak om te probeer om $u$ iets van waarde mee te deel oor die sogenaamde teorie van Statistiek.

Die oorspronklike betekenis van die term ,statistiek" was ongeveer: „die syfers van die staat”, d.w.s. dit het gedui op

\footnotetext{
* Intreerede gelewer by die aanvaarding van 'n professoraat in Statistiek
} aan die P.U. vir C.H.O., op 17 Mei 1968, deur prof. dr. J. H. Venter. 
numeriese gegewens oor onderwerpe soos bevolkingsaantalle, geboortes en sterftes, militêre sterkte, ens. Mettertyd het dié beperking tot staatkundige onderwerpe verval. Die populêre opvatting van die term is dan ook vandag nog veelal dat dit dui op tabelle syfers en grafieke oor een of ander onderwerp.

Die tegniese betekenis van die term "statistiek" is egter heelwat meer omvattend. Veral in die huidige eeu het dit steeds meer noodsaaklik geword om die metodes van ontleding en die prosesse waardeur tot gevolgtrekkings gekom word uit sulke statistiese gegewens op 'n wetenskaplike grondslag te plaas; d.w.s. die behoefte aan 'n teorie van inferensie uit statistiese gegewens het ontstaan. Waar die taak van die statistikus oorspronklik hoofsaaklik die versameling en rangskikking van gegewens was, is dft vandag ondergeskik aan sy taak as distilleerder van geldige kennis uit sulke gegewens.

Die ontwikkeling van hierdie teorie van statistiese inferensie het nog geensins tot stilstand gekom of finaliteit bereik nie. Dit is welbekend dat daar in talle wetenskappe 'n sterk neiging bestaan tot 'n steeds groter mate van kwantifisering en eksaktifisering - 'n proses waartoe Statistiek 'n groot bydrae lewer. Dít gee aanleiding tot steeds nuwe probleme en ontwikkelingsrigtings in die Statistiek veral ten opsigte van sy inferensiële sy. Ter illustrasie dien die geval van militêre en bestuurswetenskappe. Hier is dit wel nodig om geldige kennis uit statistiese gegewens te haal, maar dan dikwels slegs met die doel om te besluit watter van 'n aantal moontlike strategieë of aksies geneem moet word ten einde een of ander oogmerk te bereik. Die inferensie-probleem dra hier dus dikwels die karakter van ' $n$ beslissingsprobleem; na aanleiding hiervan word Statistiek soms, 'n bietjie ambisieus, omskryf as die wetenskap wat leer hoe wyse beslissings gemaak moet word in situasies waarby onsekerheid betrokke is.

Die onsekerheid waarvan hier sprake is, ontstaan daaruit dat statistiese gegewens meestal onvolledig is, sodat daar gewoonlik 'n mate van onsekerheid verbonde is aan die geldigheid van die gevolgtrekkings wat daaruit gemaak kan word. Dié onsekerheidsaspek word gehanteer m.b.v. begrippe uit die sogenaamde Waarskynlikheidsleer, en geen bespreking van die geaardheid en grondliggende probleme verbonde aan Statistiese Inferensie is moontlik sonder 'n ooreenkomstige bespreking t.o.v. die Waarskynlikheidsleer nie. Ek gaan dus eers hierop in. 


\section{Waarskynlikheidsleer:}

Om 'n aanknopingspunt te vind, maak ek 'n paar bewerıngs waarmee u seker sal saamstem.

(i) Dit is meer waarskynlik dat dit in Januarie meer as 3 duim in Potchefstroom sal reën as dat dit in Julie sal gebeur.

(ii) Dit is minder waarskynlik dat 'n 20-jarige persoon 60 sal word as dat 'n 25-jarige persoon dié ouderdom sal bereik.

In elke geval hier is daar sprake van 'n gebeurtenis(se) en 'n bewering omtrent die waarskynlikheid of sekerheidsgraad van die plaasvind van die gebeurtenis(se). Die Waarskynlikheidsteorie poog om betekenis en inhoud te gee aan sulke bewerings, en meer nog: om sulke kwalitatiewe bewerings soos „,meer waarskynlik..." of ,hoogs waarskynlik...", ens. te vervang deur kwantitatiewe bewerings soos „die waarskynlikheid dat dit of dat sal gebeur is $.78^{\prime \prime}$, ens. In die algemeen kan ons sê dat die Waarskynlikheidsteorie die begrip van "die sekerheidsgraad van die voorkoms van bepaalde voorvalle" probeer kwantifiseer en reëls en metodes probeer aangee waarvolgens eksakte berekenings met sulke waarskynlikhede gedoen kan word.

In die wiskundige benadering tot die Waarskynlikheidsleer word uitgegaan van twee aksiomas, nl.:

(i) Die waarskynlikheid van die plaasvind van 'n gebeurtenis is tussen 0 en 1 ; dis 1 indien dit volkome seker is, en 0 indien dit volkome seker is dat die gebeurtenis nie sal plaasvind nie.

(ii) As A en B onderling uitsluitende voorvalle is, dan is die waarskynlikheid dat $A$ of $B$ plaasvind die som van die waarskynlikhede van die plaasvind van $A$ en dié van $B$.

Dit is in die vroeë dertiger jare deur Kolmogorov ${ }^{4}$ aangetoon dat hierdie aksiomas die Waarskynlikheidsleer effektief identifiseer met die toe reeds bestaande wiskundige Maatteorie. Daarmee het 'n hele aantal bekende resultate en metodes uit die Wiskunde direk van toepassing geword; omgekeerd het probleme uit die Waarskynlikheidsleer uiters stimulerend ingewerk op die Maatteorie, met die gevolg dat die Waarskynlikheidsmaatteorie-tak van Wiskunde oor die afgelope 30 jaar en vandag nog een van die snelste groeiende rigtings in die Wiskunde was en is. Waarskynlikheidsmodelle vind vandag toepassing op sulke wyd uiteenlopende onderwerpe soos: 
die vermenigvuldiging van kerndeeltjies in kernreaktore en kosmiese buie, die voorkoms en verspreiding van epidemiese siektes in populasies, die beplanning en konstruksie van bv. telefoonsentrales en vervoerstelsels, probleme van voorraaden produksiebeheer in fabrieke, ens., om maar net 'n paar te noem.

Ondanks die onbetwisbare outoriteit en algemene aanvaarding wat die wiskundige Waarskynlikheidsleer vandag geniet, is daaraan sekere grondliggende probleme verbonde wat belangrike implikasies ook vir inferensie-toepassings inhou.

Eerstens, deurdat die Waarskynlikheidsleer gebruik maak van die wiskundige metodes van bewysvoering, is dit ook onderhewig aan die fundamentele vraagstukke wat die hele Wiskunde onderlê, nl. vraagstukke soos: wanneer is 'n bewys nou eintlik aanvaarbaar as ' $n$ bewys? Waarskynlikheidsteoretici en statistici bekommer hulle egter uiters selde oor hierdie probleme; hulle is tevrede om aan die algemeen aanvaarde standaarde van wiskundige gestrengheid te voldoen (en dikwels selfs met minder, ongelukkig!); en die probleme hieraan verbonde aan die sogenaamde ,suiwer" wiskundiges oor te laat - wat ek geensins wil goedpraat nie.

Tweedens, en van meer direkte belang, is die probleme verbonde aan die bepaling en interpretasie van waarskynlikhede. Die wiskundige Waarskynlikheidsleer gee hieroor weinig uitspraak; dit is 'n formele teorie waarin slegs bewerings gemak word van die algemene vorm: as waarskynlikhede bepaal word s 6 dat aan die aksiomas voldoen word, dan sal dit of dat volg. Die bepaling en betekenis van die basiese waarskynlikhede word dus as vooraf bekend aanvaar. In beginsel is hiermee natuurlik niks verkeerd nie: enige teorie gaan immers uit van sekere begrippe wat as vooraf bekend aanvaar word en waaruit die teorie dan opgebou word. Die probleem met die huidige aksiomatiese Waarskynlikheidsleer lê m.i. egter daarin dat dit nie ver genoeg teruggaan met sy grondbegrippe nie; dié vraagstuk kry ook nie soveel aandag as wat dit inderdaad verdien nie. Verskeie gedagterigtings oor dié kwessie bestaan egter; ek sal hier net twee bespreek nl. die empiristiese en die subjektivistiese skole.

Wat die empiristiese skool betref, word waarskynlikhede beskou as meetbare fisiese groothede (analoog aan ander fisiese groothede soos temperatuur, lengte, ens.) en meting moet 
plaasvina volgens die volgende voorskrif: As na 'n aantal onafhanklike herhalings van die situasie wat aanleiding gee tot die gebeurtenis onder beskouing, dié gebeurtenis in 'n sekere fraksie kere voorgekom het, dan is die fraksie 'n benaderde waarde van die waarskynlikheid van die gebeurtenis en hoe groter die aantal herhalings hoe beter dié benadering. Ter illustrasie dien die volgende voorbeeld: as uit die rekords van 'n versekeringsmaatskappy blyk dat uit 100,000 25-jarige mans van ' $n$ bepaalde kategorie 98,912 die 30-jarige ouderdom bereik het, dan kan die waarskynlikheid dat 'n 25-jarige man wat homself vir versekering aanmeld 30 jaar oud sal word, as .98912 geneem word, terwyl 'n meer noukeurige meting van dié waarskynlikheid verkry sal word as die ervaring van ander maatskappye met mans in dié kategorie ook in aanmerking geneem word.

Volgens dié skool kan waarskynlikhede dan alleen by benadering bepaal word, want in die praktyk kan alleen met eindige aantalle herhalings gewerk word. Vir die empiriste is dit egter geen wesentlike probleem nie omdat dit, volgens hulle, ook sal geld vir die bepaling van alle ander fisiese konstantes. Dit kan maklik aangetoon word dat die aksiomas van die wiskundige Waarskynlikheidsleer geld, as waarskynlikhede, selfs net by benadering, volgens dié voorskrif bepaal is, maar pogings van Von Mises en andere om dié metingsproses te aksiomatiseer kan tot dusver nog nie as suksesvol beskou word nie.

Kritiek teen die standpunt is o.a. dat die benadering volgens die metingsproses mank gaan aan 'n belangrike vereiste: dit is naamlik nie moontlik om vooraf met volle sekerheid te spesifiseer hoeveel herhalings nodig sal wees om 'n vooraf gespesifiseerde noukeurigheid met die benadering te bereik nie; dít hou o.a. in dat geen syfer tussen 0 en 1 as absoluut onversoenbaar met enige verkreë benadering beskou kan word nie - wat klaarblyklik ernstige twyfel werp op die geldigheid van die voorgestelde metingsproses. Binne die aksiomatiese teorie is dit wel moontlik om te bepaal hoeveel herhalings nodig is om 'n vooraf gespesifiseerde noukeurigheid te bereik, maar dan slegs met 'n waarskynlikheid van minder as 1 ; dié feit kan egter nie gebruik word om die aksiomatiek te interpreteer nie. Verder kan die empiriste ook alleen van waarskynlikhede praat in situasies van 'n herhaalbare aard; ' $n$ bewering soos dat 
die prys van 'n aandeel met 'n hoë waarskynlikheid binne 'n jaar sal verdubbel, beteken in die empiristiese opset presies niks nie - of, hoogstens, niks presies nie. Hierdie beperking hou veral ernstige implikasies in vir statistiese toepassings.

Hoewel die empiristiese standpunt redelik algemeen in statistiese kringe onderskryf word, kan die fundering daarvan nie as bevredigend aanvaar word nie. Nogtans vind ons sterk getuienis daarvoor dat hierdie benadering kan lei tot prakties bruikbare resultate en suksesvolle metodes in o.a. die florering van talle versekeringsmaatskappye en ander bedrywe wat van die benadering gebruik maak.

Die subjektivistiese standpunt ontken die bestaan van waarskynlikhede as objektief meetbare fisiese groothede; waarskynlikhede word hier beskou as mate van die vertroue of sekerheid wat bepaalde individue of instansies het in die waarheid van gegewe proposisies, bv. die proposisie dat ' $n$ bepaalde persoon 60 jaar oud sal word of dat die prys van 'n bepaalde aandeel sal styg. Dié standpunt postuleer dat die persoon „redelik" sal wees in sekere opsigte, maar dit ontken nie dat twee sulke redelike persone verskillende grade van vertroue kan hê in die waarheid van dieselfde proposisie nie al het hulle albei insae in dieselfde objektiewe getuienis betreffende die bewering. Net so kan dieselfde persoon op verskillende tye verskillende grade van sekerheid hê oor 'n bepaalde bewering. Ter illustrasie van die tipe oorweging wat hierdie standpunt onderlê, beskou die volgende situasie: Gestel 'n 50-jarige persoon doen aansoek om lewensversekering ten bedrae van R1m by 'n maatskappy; in sulke gevalle sal die maatskappy nie gewone tariewe kwoteer nie en 'n spesiale premieberekening sal nodig wees; hiervoor sal dit nodig wees om die waarskynlikhede dat die persoon respektieflik $51,52,53, \ldots$ sal word, te bepaal. Die maatskappy sal dié waarskynlikhede nie sommer ligtelik oorskat nie, want dit kan 'n te lae premie en gevolglike verlies meebring; dit sal dié waarskynlikhede ook nie ligtelik onderskat nie, want dit kan lei tot 'n te hoë premie en 'n gevolglike verlies van besigheid aan 'n mededinger. Om dié waarskynlikhede te bepaal kan die maatskappy sy rekords oor soortgelyke gevalle ondersoek, die persoon se mediese geskiedenis bestudeer, ens., maar dit ly geen twyfel nie dat die waarskynlikhede waarop uiteindelik besluit sal word, nie uitsluitlik deur sulke objektiewe getuienis bepaal sal word 
nie. Subjektiewe oorwegings sal beslis ook 'n rol speel. Uit die aard van die subjektivistiese standpunt, kan die presiese bepalingsproses nie nader gespesifiseer word nie. Hoe ook al uiteindelik bepaal, as die maatskappy die persoon se waarskynlikheid om 51 te word as laer beskou as sy waarskynlikheid om 52 te word, dan sou sy waarskynlikhede nie konsekwent wees met die wiskundige Waarskynlikheidsteorie nie die bepalings moet dus ,redelik" wees in dié opsig.

Die voorstanders van hierdie standpunt (waaronder veral Savage $)^{\circ}$ het 'n algemene teorie opgestel waarin uitgegaan word van 'n aantal postulate omtrent die gedrag van 'n „,rasionele" of „redelike" persoon of instansie in bepaalde keusesituasies. Hulle toon dan aan dat dié postulate die bestaan impliseer van waarskynlikhede wat voldoen aan die aksiomas van die wiskundige Waarskynlikheidsleer. 'n Subjektivis sal dus, by beoefening van die Waarskymlikheidsleer, homself eers moet oortuig dat hy redelik is in die sin dat hy aan die genoemde postulate voldoen; daarna kan hy waarskynlikhede bepaal volgens sy intuïtiewe en subjektiewe insigte en sover doenlik deur gebruikmaking van sulke ander getuienis as wat hy beskikbaar het. Dit mag bv. wees dat sulke objektiewe inligting oorweldigend is deurdat daar bv. groot aantalle herhalings van die empiriese soort bestaan; dán sal daar moontlik min verskil tussen empiris en subjektivis bestaan wat betref hulle bepalings (maar nie wat betref hulle interpretasies nie!). Daar hoef egter nie noodwendig sulke objektiewe inligting te bestaan vir die subjektivis om sy presiese bepalings te kan maak nie, en bowendien is hy ook bereid om waarskynlikhede toe te ken aan gebeurtenisse (of, om presies te wees, die waarheid van die bewerings dat die gebeurtenisse sal plaasvind) waarby so iets nie vir die empiris ter sprake kan wees nie.

Kritiek teen die standpunt was en is nog steeds heftig. Die mees algemene stelling is dat dit wat ons „wetenskap" of „wetenskaplike metode" noem, al is dit ietwat vae begrippe, grotendeels daarop gemik is om vas te stel dit (d.i. wetmatighede, ens.) wat hoogs moontlik waar is en wel volgens kriteria waaroor daar binne redelike perke eenstemmigheid kan wees; 'n Waarskynlikheidsleer met die oog op wetenskaplike toepassings behoort dus 'n kodifisering te wees van sulke universeel aanvaarbare kriteria. Van Dantzig ${ }^{2}$ het bv. opgemerk dat 'n Fisika waarin termometers geyk word deur persone wat hulleself 
afvra hoe warm dit is, ondenkbaar is. Analoë kritiek kom ult die rigting van praktiese gebruikers: Indien bv. die subjektivistiese versekeraar, al sou hy redelik wees in die tegniese sin van die woord, ook van nature 'n optimis was en binne die perke van vryheid wat sy subjektivistiese beginsels hom gun, die oorlewingswaarskynlikhede van sy kliënte meestal oorskat het, dan sou sy eie oorlewingskanse daaronder ly. Dit is ook duidelik dat alleen hoogs geïdealiseerde persone aan die postulate van dié skool sal kan voldoen, maar daar bestaan geen metodes of toetse met behulp waarvan voornemende persone kan verseker dat hulle dié toestand bereik nie. Dit bly ook in die laaste instansie nog onduidelik presies hoe selfs die oortuigde subjektivis te werk sal gaan om sy waarskynlikhede te kry. Op hierdie kritiek bestaan daar natuurlik gedeeltelike antwoorde, maar ek wil nie nou daarop ingaan nie.

Daar bestaan nog talle ander gedagterigtings oor die kwessie van die betekenis en bepaling van waarskynlikhede; selfs binne die skole wat ek genoem het, is daar talle strominge. Verder beweer sommige outoriteite dat verskillende interpretasies moontlik is, afhangende van omstandighede; ander weer beweer dat die onenigheid eintlik net skyn is en hoofsaaklik terminologies van aard en dat dit sal verdwyn sodra 'n diepgaande genoeg ontleding gedoen is - sommige, in die woorde van Savage," beweer selfs dat hulle self alreeds dié benodigde ontleding gedoen het! Nogtans is daar geen eenstemmigheid en algemene aanvaarding van die een of ander standpunt t.o.v. die vraagstuk nie.

\section{Statistiese inferensie:}

Ons keer nou terug na die Statistiek, en ek sal probeer om hier enkele van die belangrikste fasette van die inferensieproses toe te lig, aan te dui watter rol die Waarskynlikheidsleer hierin speel en 'n paar gedagtes in dié verband te stel.

Om mee te begin, sal ek een van die vernaamste algemene probleme uit die sogenaamde klassieke Statistiek aanroer, nl. die probleem van hipotese-toetsing. Hier het ons te doen met een of ander versameling van voorwerpe waarna gewoonlik as 'n populasie verwys word; die waarheid van een of ander hipotese omtrent die populasie moet getoets word. Om die gedagtes beter te bepaal, kan ons in terme van die volgende voorbeeld 
praat: 'n Koper oorweeg die aankoop van 10,000 artikels; die verkoper beweer dat die persentasie defektiewes in die lot nie meer as $5 \%$ is nie; die koper wil dié bewering toets. Om volkome sekerheid oor die waarheid hiervan te kry, sou byna alle artikels ondersoek moes word; gestel dit is prakties nie moontlik nie omdat, sê maar, ondersoek vernietiging van die artikels meebring. Om definitief te wees, gestel $100 \mathrm{kan}$ ondersoek word en veronderstel dit lewer 9 defektiewes op. Die koper sal dan geneig wees om die verkoper se bewering in twyfel te trek (en op 'n prysverlaging aandring); die verkoper daarenteë, sal argumenteer dat dit maklik kan gebeur dat 'n steekproef gekry word wat, soos die koper s'n, relatief meer defektiewes insluit as wat daar in die hele populasie is en dat dit gevolglik geen afbreuk doen aan sy stelling nie. Dit is duidelik dat beide kante 'n mate van reg het hier; die statistiese teorie van hipotese-toetsing kan help om tussen dié twee standpunte te kies, soos ek sal probeer aandui.

Eerstens is dit duidelik dat geen vordering gemaak sal kan word nie indien ons nie weet hoe die steekproef getrek is nie; intuïtief is dit duidelik dat 'n goed verteenwoordigende steekproef getrek behoort te word, maar iets meer spesifieks is nodig vir die opstelling van 'n algemene teorie. Die gebruiklike uitgangspunt van die Statistiek is dat die steekproef ewekansig gekies word, d.w.s. dat die reël geld dat by elke keuse van 'n element uit die populasie alle beskikbare elemente dieselfde waarskynlikheid het om gekies te word. Dit is, terloops, presies hierdie reël wat meebring dat Statistiek 'n waarskynlikheidskarakter kry; ons kom aanstons hierop terug. Voorlopig kan ons opmerk dat, hoewel dié reël nie noodwendig met absolute sekerheid 'n verteenwoordigende steekproef sal oplewer nie, sal die waarskynlikheid van uiterste bevooroordeeldheid in die algemeen klein wees, veral by groter steekproewe; bowendien, en dis van meer belang, kan dié moontlikheid eksplisiet in berekening gebring word.

Voordat ons met ons voorbeeld voortgaan, herinner ek $u$ net aan die volgende redelik algemene, hoewel ietwat vaag gedefinieerde, metode van wetenskaplike inferensie. Op die een of ander wyse word 'n teorie, wet of hipotese geformuleer oor sekere verskynsels onder beskouing. Dié hipotese is miskien sodanig dat dit nie direk eksperimenteel getoets kan word nie, maar indien dit waar is, moet noodwendig geld 'n sekere kon- 
klusie of voorspelling wat wel direk eksperimenteel getoets kan word; indien dit nou blyk dat die voorspelling nie strook met die eksperimentele gegewens nie, dan kan die hipotese as vals verwerp word, terwyl as die voorspelling wél strook met die eksperimentele gegewens, dan volg die geldigheid van die hipotese nog nie noodwendig nie en kan die resultate van die eksperiment hoogstens as getuienis ter ondersteuning van die hipotese beskou word. Die geskiedenis van die wetenskap lewer talle voorbeelde van die werking van hierdie inferensieproses.

By statistiese toepassings moet hierdie program ietwat gewysig word: hier is dit meestal die geval dat alle voorspellings wat met absolute sekerheid waar sal wees as die betrokke hipotese waar is, so algemeen is dat dit buitendien (d.i. of die hipotese nou waar is of nie) met geen eksperimentele gegewens in stryd sal wees nie. Hierdie moeilikheid kan oorkom word deur van die voorspellings waarmee gewerk word, slegs te verwag dat dit met 'n hoë waarskynlikheid waar sal wees as die hipotese waar is; indien die eksperimentele resultate dan nog nie strook met so 'n voorspelling nie, kan met hoë waarskynlikheid besluit word dat die hipotese vals is; anders kan weinig spesifieks afgelei word tensy dat verdere ontledings gedoen word.

Hierdie idees, toegepas op ons koper-verkoper voorbeeld, lewer die volgende: die hipotese is hier dat die persentasie defektiewes in die populasie minder as $5 \%$ is; m.b.v. die Waarskynlikheidsleer kan dit aangetoon word dat vir 'n ewekansige steekproef van 100 met 'n waarskynlikheid hoër as .95 sal die aantal defektiewes 8 of minder wees indien dié hipotese waar is; die voorspelling is dus dat 8 of minder defektiewes in die steekproef gekry sal word. Die koper het 9 gekry; dit strook nie met die voorspelling nie; indien die steekproef ewekansig gekies was, kan ons die hipotese dus verwerp en die koper gelyk gee. Indien die steekproef 7 defektiewes opgelewer het, sou weinig gesê kon word en in besonder sou dit tog nie geregverdig wees om sonder meer die verkoper se hipotese as waar te aanvaar nie, soos ongelukkig dikwels in die praktyk gedoen word.

In die algemeen bestaan daar vryheid van keuse t.o.v. die voorspellings wat gebruik kan word om 'n hipotese te toets; dit is dus wenslik om daardie keuse te maak wat tot die gevoeligste toets lei, d.i. dié voorspelling wat by 'n gegewe waarskynlikheid om met die eksperimentele gegewens te strook as die hipotese 
waar is, so 'n hoogs moontlike waarskynlikheid het om nie daarmee te strook nie as dit vals is. Dit kan inderdaad aangetoon word dat die toets wat ons in ons voorbeeld gebruik het, die beste moontlike is in hierdie sin. In die algemeen is hierdie een van die belangrike probleme wat bestudeer word in die teorie van hipotese-toetsing; in talle gevalle is reeds volledige oplossings hiervoor bekend. Binne die raamwerk van die wiskundige Waarskynlikheidsleer bestaan daar dus 'n goed ontwikkelde teorie oor die probleem van hipotese-toetsing in statistiese situasies; dié teorie vind toepassings op o.a. landboukundige eksperimentering, asook in talle ander empiriese wetenskappe.

Daar is egter probleme verbonde aan die interpretasie van hierdie teorie. Uit die subjektivistiese oogpunt gesien, kan die resultaat van die toets in ons voorbeeld interpreteer word as betekenende dat die koper .95 sekerheid kan hê in die waarheid van die bewering dat die persentasie defektiewes in die lot groter as $5 \%$ is. Hierteen sal 'n empiris beswaar maak: die persentasie defektiewes is ò groter as $5 \%$ of kleiner as $5 \%$ en die waarskynlikheid van elk van hierdie moontlikhede is ò 0 òf 1 , d.i. dié bewering is een van dié waaraan hy geen egte waarskynlikhede wil toeken nie. Die korrekte interpretasie van die resultaat van die toets uit sy oogpunt gesien, is dus dit: die hipotese is getoets (en in die huidige geval verwerp) volgens 'n prosedure wat in minstens 95\% van alle gevalle waarop dit toegepas word, geldige hipoteses nie sal verwerp nie. Die .95 waarskynlikheid slaan dus op die toetsingsprosedure: dis 'n eienskap hiervan en het alleen langs 'n omweg iets te doen met die onderhawige fisiese situasie. Of bv. die huidige verwerping een van die $95 \%$ van alle gevalle van korrekte beslissing is, kan volgens die interpretasie nie gesê word nie. In situasies waar dikwels van sulke toetse gebruik gemaak word, kan moontlik nog 'n mate van regverdiging vir die gebruik van sulke toetse uit só 'n standpunt gevind word maar, en dis dikwels in die praktyk die geval, as slegs een enkele toepassing van belang is, lei die empiristiese standpunt tot 'n interpretasie wat m.i. die gebruik van sulke toetse van 'n twyfelagtige waarde maak. Die subjektivistiese oogpunt hou m.i. hier veel meer belofte in, hoewel ek nie dié standpunt in sy huidige vorm ten volle kan onderskryf nie. Daar is natuurlik ook nog die keuse van sekerheidsgraad waarmee die voorspel- 
ling waarmee gewerk word, moet geld as die hipotese waar is (.95 is in ons voorbeeld gekies); selfs die empiriste gee toe dat dit, feitlik in sy geheel, alleen uit subjektiewe oorwegings gemotiveer kan word.

Hierdie probleme kom die Statistiek natuurlik binne saam met die invoering van waarskynlikheidsbegrippe; die vraag ontstaan dus of dít nie vermy sou kon gewees het deur as uitgangspunt te gebruik steekproewe wat nie volgens 'n waarskynlikheidsreël gekies is nie. Oor die vooruitsigte op geslaagdheid van so 'n teorie twyfel ek. In die praktyk gebeur dit dikwels dat steekproewe geneem word sonder dat daar bewustelik sorg gedra word dat die een of ander spesifieke reël geld. Streng gesproke is geen ontleding dan moontlik nie, maar die aanname dat die steekproef ewekansig gekies is, is dikwels 'n goeie benadering vir dié onreëlmatige reël. Vir alle praktiese doeleindes kan die ontledings gebaseer op ewekansigheid, d.i. die gewone statistiese inferensie-metodes, dan tog nogtans uitgevoer word. Hierdeur word die trefwydte van dié tegnieke natuurlik heelwat uitgebrei. Dis te betwyfel of enige teorie van Statistiese Inferensie wat op iets anders as 'n waarskynlikheidsreël van steekproefneming gegrond is, ook dié eienskap sal hê.

Hipotese-toetsing is net een deel van die Statistiese Inferensie. Indien ons koper se probleem was dat hy slegs ' $n$ bepaling van die onbekende persentasie defektiewes wou maak, heeltemal afgesien van wat die verkoper daaromtrent beweer, het hy 'n sogenaamde skattingsprobleem gehad; indien hy 'n idee van die betroubaarheid van dié skatting wou hê, was sy probleem een van betroubaarheidsgrense, ens. In elk van dié rigtings bestaan uitgebreide resultate en dikwels volledige oplossings. Hierdie onderwerpe vorm almal deel van die sogenaamde klassieke Statistiek. Klassiek, terloops, verwys hier na dinge wat meestal nie ouer as 40 jaar is nie. Ongeveer 20 jaar gelede is 'n nuwe teorie ontwikkel deur Wald' wat tot ' $n$ groot mate al bogenoemde rigtings insluit as spesiale gevalle. Hierdie sogenaamde Beslissingsteorie het sedertdien 'n groot invloed uitgeoefen op die Statistiek, beide wat die teorie en wat die praktyk betref, en dit moet m.i. beskou word as een van die belangrikste ontwikkelings in die geskiedenis van Statistiek.

Om 'n idee te vorm van wat hierdie teorie behels, kan ons weer na die koper-verkoper probleem kyk. Vir die koper sal 
die geldigheid al dan nie van die verkoper se bewering dat hoogstens $5 \%$ defektief is, van weinig direkte belang wees. Laat ons aanneem dat die koper tussen twee aksies moet besluit, nl. om te koop of om nie te koop nie; meer as 2 aksies kan natuurlik ook toegelaat word. Die eventuele wins (of verlies) wat die koper uit die transaksie sal maak, sal afhang van watter aksie hy neem en van wat die werklike persentasie defektiewes is. Veronderstel dat dié wins bepaal kan word by elke moontlike aksie en vir elke moontlike persentasie defektiewes. Indien die persentasie defektiewes nou bekend was, kon bepaal word watter van die twee aksies die hoër wins oplewer en die koper sou daarop kon besluit het. Ongelukkig is dié persentasie egter nie bekend nie en kan alleen 'n steekproef geneem word waaruit inligting hieromtrent verkry kan word. Dié inligting kan dan aangewend word m.b.v. 'n beslissingsreël, d.i. 'n reël wat by elke moontlike aantal defektiewes wat in die steekproef kan voorkom, sê watter aksie geneem moet word, bv. die reël dat as daar 9 of minder defektiewes is, koop, anders nie. Met behulp van die winsfunksie kan die gevolge van enige voorgestelde beslissingsreël nou kwantitatief bepaal word. ' $n$ Kriterium waarvolgens beslissingsreëls beoordeel kan word, ontstaan sodoende en die oplossing van die probleem lê dan in die bepaling van 'n optimale beslissingsreël. Hierdie voorbeeld het reeds al die kenmerke van die algemene beslissingsprobleem; dit bestaan naamlik uit drie fases: eerstens moet die moontlike aksies met alle moontlike gevolge bepaal word, tweedens moet alle relevante inligting verkry word en derdens moet die beslissingsreël wat dié inligting ten beste gebruik om tussen die aksies te kies, bepaal word.

Die ontwikkeling van hierdie teorie het ' $n$ natuurlike benadering moontlik gemaak tot talle probleme wat vroeër alleen op 'n geforseerde wyse geformuleer kon word om in te pas by die toe bestaande tegnieke van Inferensie. Bowendien kan dit aangetoon word dat meeste van die probleme van die klassieke Statistiek ook in terme van die Beslissingsteorie geformuleer kan word. Hierdie feit het 'n herwaardering van baie voorgestelde oplossings vir sulke probleme teweeggebring en 'n veel sterker motivering van talle ander. Sodoende het dié ontwikkeling beide betekenisvolle verdieping en uitbreiding van die teorie van die Statistiese Inferensie meegebring.

Die grootste swakpunt van dié teorie lê by die bepaling 
van die gevolge van die verskillende moontlike aksies. In handels- en Industriële-tipe toepassings waar alle faktore dikwels in geldeenhede omgesit kan word, is dit gewoonlik nie so 'n onoorkomelike moeilikheid nie, maar in bv. natuurwetenskaplike toepassings, is dit meestal 'n onbegonne taak. Hier is dit nogtans moontlik om een of ander bloot konvensionele keuse te maak, maar die feit bly dat die formulering van inferensieprobleme uit dié oord in die terme van die Beslissingsteorie dikwels kunsmatig is. Verder is daar ook 'n aantal intuitief aanvaarbare statistiese tegnieke wat slegs moeilik uit die oogpunt van die Beslissingsteorie regverdigbaar is (die sogenaamde aanneemlikheidsmetodes). As gevolg hiervan vind mens dat talle outoriteite die waarde van dié teorie vir die Statistiek ontken, of geringskat. Kendall ${ }^{3}$ bv. bestee in 'n 3-volume werk slegs 'n halfbladsy hieraan. M.i. is dit uiters ongelukkig, want hierdeur gaan die eenheid van die vakgebied, die groter eksaktheid van denke en argumentering en die helderheid van perspektief wat deur dié teorie meegebring is, verlore.

Daar is nog vele ander strominge in die Statistiese Inferensie. Miskien is die belangrikste gedagterigting onder die wat nog nie genoem is nie, die sogenaamde Bayesmetodes. Hierdie stroming bestaan uit 'n groep Inferensiemetodes wat sentreer om die sogenaamde stelling van Bayes,' 'n resultaat in die Waarskynlikheidsleer wat in die $18 \mathrm{e}$ eeu deur die rev. Bayes ontdek is. Die stelling is op 'n dikwels onregverdigbare wyse as inferensiemiddel gebruik en dié gebruik is mettertyd so sterk gekritiseer, dat dit verval het. Veral egter onder aansporing van die subjektivistiese skool in die Waarskynlikheidsleer, het daar sterk vernuwing t.o.v. die gebruik van Bayes se stelling gekom; rofweg gesproke, dien dit as tegniese middel met behulp waarvan subjektiewe oordeel en objektiewe of eksperimentele gegewens gekombineer kan word om tot 'n finale oordeel met die oog op inferensie te kom. Dié metodes is besig om vandag veld te wen beide as blote tegniese hulpmiddels in die bestudering van teoretiese probleme en as bona fide-inferensie metodes. Terwyl daar weinig kritiek teen die tegniese gebruike van die Bayesmetodes kan bestaan, twyfel talle nog steeds (en ek is geneig om hulle gelyk te gee) oor die regverdigbaarheid van ander toepassings.

Hierbo het ek probeer om $u$ 'n indruk te gee van enkele fasette van die Statistiese Inferensie en die daarmee samehan- 
gende vraagstukke. As gevolg van die nadruk op die problematiese in die onderwerp, mag ek die indruk laat ontstaan het dat die onderwerp in 'n aansienlike mate van verwarring verkeer en die waarde van die gebruik van statistiese tegnieke mag twyfelagtig voorkom. Hierdie indruk sou misleidend wees. Dit ly geen twyfel nie dat Statistiek 'n uiters waardevolle hulpmiddel in byna alle wetenskappe en bedrywe kan wees, veral dié met 'n empiriese karakter. Die situasie is analoog aan die in ander wetenskappe; bv. die feit dat daar geen volkome eenstemmigheid bestaan oor die presiese geaardheid van 'n elektron nie, verhinder fisici nie om prakties suksesvolle aanwendings van hulle kennis van sekere eienskappe daarvan te maak nie soos bv. deur ' $n$ radio te bou. Net so beskik statistici vandag oor 'n goed ontwikkelde en snel uitbreidende arsenaal van tegnieke en modelle wat hulle in staat stel om prakties suksesvolle oplossings te gee aan 'n wyd-uiteenlopende verskeidenheid van probleme. Dit is ook interessant dat die verskillende moontlike benaderings tot dieselfde probleem, dikwels dieselfde oplossing of byna dieselfde oplossing in die praktyk lewer 'n feit wat natuurlik meehelp om vertroue in dié tegnieke te bevestig.

\section{Verdere opmerkings:}

Ek sluit af met twee losstaande gedagtes van min of meer algemene belang:

Statistiek is tot 'n groot mate 'n hulpwetenskap; terwyl dit as sulks reeds goeie erkenning in ander wetenskappe geniet, kan dieselfde nie gesê word wat nywerheid en bedryf betref nie. Ondervinding hier het geleer dat statistiese probleme dikwels nie as sulks herken word nie en dat daar gevolglik dikwels nie veel teregkom van doeltreffende oplossing en hantering van sulke probleme nie. Deels verantwoordelik hiervoor is gebrekkige of verkeerde opleiding t.o.v. Statistiek van die personeel aan wie sulke probleme toevertrou word asook verouderde idees omtrent die taak van statistici. Hierdie ongewenste toedrag van sake kan oorkom word deur 'n groter gebruikmaking van statistici op ' $n$ raadgewende basis, en hierin kan en behoort universiteite ' $n$ belangrike rol te speel. Wat nodig is, is groter bewustheid van die kant van die praktyk t.o.v. die mate van hulp wat hy van die akademie kan kry by die be. 
studering en oplossing van sy probleme en ook 'n groter belangstelling van die kant van die akademie in die probleme van die praktyk. Dit ly geen twyfel nie dat beide kante alleen voordeel kan trek uit die oorbrugging van die gaping wat hier bestaan.

Statistiek is ook nog 'n relatief jong en onbekende wetenskap; veral voornemende studente weet meestal min hiervan en het weinig motivering om dit as loopbaan te kies. Gevolglik vind ons dat nie genoeg studente, en veral nie genoeg met 'n goeie potensiaal, in dié rigting wil studeer nie. Deels verantwoordelik hiervoor en 'n faktor wat uitgeskakel kan word, is $m$.i. die feit dat Suid-Afrikaanse skoolleerplanne geen voorsiening maak vir selfs elementêre onderrig hierin nie. Met die onlangse hersiening van leerplanne vir Wiskunde kon bv. maklik voorsiening gemaak gewees het vir die insluiting van iets oor Waarskynlikheidsleer; dit sou op 'n baie natuurlike wyse aangesluit het by die versamelingsleeruitgangspunt wat met dié leerplanne ingevoer is. Hierdie saak behoort m.i. ernstige oorweging te geniet.

\section{Enkele verwysings:}

1. Bayes, T. (1958): An essay toward solving a problem in the doctrine of chances. Biometrika, Vol. 46, p. 293. (Die oorspronklike het in 1763 in die Phil. Trans. Royal Soc., p. 370 verskyn).

2. Bremekamp, H., et al. (1940): Waarschijnlijkheidsrekening en statistische methoden. Symposium van het Wiskundig Genootschap; Ned. T. Natuurk. 8, 1-83.

3. Kendall, W. G. \& Stuart, A. (1958-66): The advanced theory of statistics. Griffin.

4. Kolmogorov, A. N. (1950): Foundations of the theory of probability. Chelsea. (Die oorspronklike Duitse uitgawe het in 1933 verskyn).

5. Newman, J. R. (1956): The world of mathematics, p. 2053. Allen and Unwin.

6. Savage, L. J. (1954): The foundations of statistics; Wiley

7. Wald, A. (1950): Statistical decision functions; Wiley. 